\title{
Visceral leishmaniasis in Rio de Janeiro, Brazil: eco-epidemiological aspects and control
}

\author{
Leishmaniose visceral no Rio de Janeiro, Brasil: \\ aspectos eco-epidemiológicos e controle
}

\author{
Mauro Celio de Almeida Marzochi ${ }^{1}$, Aline Fagundes ${ }^{1}$, Moacir Vieira de Andrade ${ }^{2}$, \\ Marcos Barbosa de Souza ${ }^{3}$, Maria de Fátima Madeira ${ }^{1}$, Eliame Mouta-Confort ${ }^{1}$, \\ Armando de Oliveira Schubach ${ }^{1}$ and Keyla Belizia Feldman Marzochi ${ }^{1}$
}

\begin{abstract}
From 1977 (index case) to 2006, 87 cases of visceral leishmaniasis were confirmed in the municipality of Rio de Janeiro, Brazil, in periurban areas on the continental and coastal slopes of the Pedra Branca massif and the continental slopes of the Gericinó massif. The majority (65.5\%) of the patients were more than five years old, predominantly males (61.5\%), but without any difference between the sexes below the age of 14 years. The overall fatality rate was $10.4 \%$. Two cases of visceral leishmaniasis/human immunodeficiency virus coinfection were detected. Leishmania chagasi was isolated from human and canine cases. The associations between the presence of phlebotomines and human and canine migrations, disorderly occupation involving degradation of environmental preservation areas and poor socioeconomic conditions may have created a favorable setting for the establishment and propagation of the disease. Close epidemiological surveillance associated with traditional control measures and others (active case researches, land clearing and health education), reduced the incidence of human cases from 2.8 per 100,000 inhabitants in 1981 to less than 0.01 per 100,000 since 1997. The canine infection rates decreased from 4.6\% in 1984 to 1.6\% in 2008. Lutzomyia longipalpis was not detected in some locations where human and canine cases occurred. In the years 2007 and 2008, no new human cases were reported, but there is a persistent and worrisome residual canine seroprevalence.
\end{abstract}

Key-words: Visceral leishmaniasis. Eco-epidemiology. Environmental factors. Control. Rio de Janeiro.

\section{RESUMO}

Entre 1977 (caso índice) e 2006 foram confirmados 87 casos de leishmaniose visceral no Município do Rio de Janeiro, oriundos de áreas peri-urbanas das vertentes continentais e litorâneas do Maciço da Pedra Branca e das vertentes continentais do Maciço do Gericinó. A maioria (65,5\%) dos pacientes tinha mais de 5 anos de idade, prevalecendo o sexo masculino (61,5\%), sem diferença de frequiência entre os sexos até os 14 anos. A letalidade foi de 10,4\%. Houve dois casos de co-infecção por leishmaniose visceral/vírus da imunodeficiência. Leishmania chagasi foi isolada de casos humanos e caninos. Presença de flebotomíneos associada a migrações humanas e caninas, ocupação desordenada degradando áreas de preservação ambiental e baixas condições socioeconômicas podem ter criado o contexto propício à instalação e à propagação da endemia. Vigilância epidemiológica estreita com as medidas tradicionais de controle e outras - busca ativa de pacientes, limpeza de terrenos e educação em saúde -, reduziram a incidência de casos humanos de 2,8 por 100 mil habitantes em 1981 para menos de 0,01 por 100 mil a partir de 1997. As taxas de infecção canina decresceram de 4,6\% em 1984 para 1,6\% em 2008. Lutzomyia longipalpis não foi detectada em algumas localidades onde ocorreram casos humanos e caninos. Em 2007 e 2008, nenhum novo caso da doença humana foi notificado, mas permanece uma preocupante prevalência sorológica residual canina.

Palavras-chaves: Leishmaniose visceral. Eco-epidemiologia. Fatores ambientais. Controle. Rio de Janeiro.

In Brazil, visceral leishmaniasis (VL) or neotropical kala-azar is an endemic/epidemic rural and periurban anthropozoonosis with a strong tendency towards urbanization. Dogs form an important household reservoir for the etiological agent, Leishmania

1. Laboratory for Leishmaniasis Surveillance, Evandro Chagas Clinical Research Institute, Fiocruz. Rio de Janeiro, RJ, Brazil. 2. Municipal Health Secretariat, Rio de Janeiro, RJ, 3. Sergio Arouca National School of Public Health, Fiocruz, Rio de Janeiro, RJ, Brazil

Financial Support: This study was partially funded by the Brazilian National Research Council (CNPq) - MCA Marzochi is a Senior Researcher from CNPq.

Address to: Prof. Mauro Célio de Almeida Marzochi. Laboratório de Vigilância em Leishmanioses/IPEC/FIOCRUZ. Av. Brasil 4365, 21040-900 Rio de Janeiro, RJ, Brazil. Tel: $55213865-9541$

e-mail: mauro.marzochi@ipec.fiocruz.br

Received in 09/03/2009

Accepted in 14/08/2009
chagasi/Leishmania infantum. The importance of the canine reservoir derives from the close, frequent contact between dogs and humans and the fact that the animals can present asymptomatic infection, despite a high degree of parasitism in healthy skin and viscera $^{2} 111830$. The disease can evolve to the serious and fatal form $^{2338}$.

Since the initial studies in Brazil, the experience has been that the human disease differs little from the other clinical and epidemiological types that occur on other continents, especially in the Mediterranean region, including fever, anemia, hepatosplenomegaly and progressive wasting ${ }^{39}$. Fatality in untreated cases is high, but this can be reduced substantially through the response to antimonial treatment, with amphotericin $\mathrm{B}$ and its liposomal formulations as alternative drugs ${ }^{21}{ }^{40}$. 
Various authors have also acknowledged the occurrence of oligosymptomatic, incomplete forms ${ }^{353}$, along with unapparent/ asymptomatic or subclinical infection ${ }^{2729}$. Marzochi \& Marzochi ${ }^{27}$ proposed a subclinical or unapparent form of visceral leishmaniasis characterized by absence of clinical manifestations (signs and symptoms) based on negative anamnesis and normal physical examination, presence of antibodies and/or positive delayed hypersensitivity skin test (DHST), as recommended by the guidelines of the Brazilian Ministry of Health ${ }^{49}$. However, the exclusive presence of positive DHST is only valid for endemic VL areas. Findings of unapparent VL may reflect the initial infectious process that will eventually evolve to disease, or involution, i.e. the self-resolving phase of the initial process (the ideal parasite-host equilibrium relationship). Such findings may also represent an immune postdisease residue in treated cases $^{27}$. The unapparent form of the infection can only be found through actively searching for cases, and treatment is normally not indicated in such cases but, rather, they should be subject to clinical follow-up ${ }^{27}$. All these questions still demand further study, especially with the growth of urban VL.

The principal insect vector, Lutzomyia longipalpis, easily colonizes the areas surrounding homes, adapting to high temperatures and low humidity. In addition to its geographical spread, this phlebotomine has been shown to adapt both to periurban and to urban environments, with a tendency to invade homes. The highest transmission rates occur during the rainy season. The females are hematophagous, and when they invade homes and the areas surrounding them, they bite humans and dogs, as well as poultry, horses and synanthropic animals in surrounding $\operatorname{areas}^{111450}$.

The expanding geographical distribution and population increase of Lutzomyia longipalpis in southern Brazil, in areas where it had never or only rarely been observed, would explain the appearance of new VL foci ${ }^{28}$. However, in central-western Brazil, another phlebotomine species, Lutzomyia cruzi, has also been incriminated in VL transmission ${ }^{48}$.

Over the last three decades, in addition to the expansion of endemic areas in northeastern Brazil ${ }^{10}$, new foci have been detected in other regions of the country, thus characterizing expansion of the endemic disease along with a tendency towards urbanization 25272829 . According to the Ministry of Health, more than 3,000 human cases continue to occur annually in Brazil, with a geographical distribution ranging from the north of the Amazon region to the southeastern region of the country, traversing the central-western region, although persistently predominating in the northeast ( $77 \%$ of cases). For the country as a whole, the most heavily affected states are Bahia, Ceará, Maranhão and Piauí, with $66 \%$ of all cases ${ }^{49}$.

In most areas of Brazil, endemic VL is more frequent among children. Until the 1970 s, children under 10 years of age accounted for $80 \%$ of cases, with children less than 5 years of age accounting for $60 \%$ of the total (predominately males). Currently, the prevalence has decreased among children under 10 years of age (now accounting for around $50 \%$ of the cases), but $41 \%$ of the patients are still four years of age or younger, and males still predominate. The age profile has changed as the endemic has spread to new areas ${ }^{49} 58$.
In southeastern Brazil in the 1970s, the States of Minas Gerais and Espírito Santo began to show an increasing endemic rural pattern of human and canine VL cases, along the Rio Doce valley ${ }^{20}$. In the municipality of Rio de Janeiro, the disease appeared in periurban areas beginning in 1977 . By the 1980s, VL was considered urbanized in the metropolitan areas of Teresina (State of Piauí) and Belo Horizonte and Montes Claros (State of Minas Gerais). More recently, in the 1990s, the disease appeared in municipalities in the west of the state of São Paulo ${ }^{49}$, particularly in the City of Araçatuba, which has extensive commerce with VLendemic municipalities in the state of Mato Grosso do Sul, such as Campo Grande and Três Lagoas, in the central-western region of the country.

The State of Rio de Janeiro was considered free of human VL until August 1977, when the disease was detected in the state capital for the first time, in the periurban Bangu neighborhood. The index case was a 55-year-old male who eventually died of the disease ${ }^{47}$. By August 2006, 87 autochthonous cases had been diagnosed, all from periurban areas on the western side of the city. The municipality of Rio de Janeiro is divided administratively into five planning areas (PAs), or the equivalent of boroughs, which in turn are divided into 34 administrative regions (ARs), the latter including various neighborhoods and locations. The areas with visceral leishmaniasis cases are located: in PA-5, on the continental slopes of the Pedra Branca massif, in the Bangu and Realengo neighborhoods of Bangu and Realengo ARs, respectively, and on the Gericinó massif, in the neighborhood of Gericinó, in the locations known as Mendanha, Guandu do Sena and Vila Kennedy, situated in Bangu AR, and on the coastal slopes of the Pedra Branca massif, in the Campo Grande neighborhood of Campo Grande AR and the neighborhoods of Guaratiba, Barra de Guaratiba and Pedra de Guaratiba of Guaratiba AR; and in PA-4, in the Curicica and Taquara neighborhoods of Jacarepaguá AR and the neighborhoods of Barra da Tijuca, Camorim, Vargem Grande and Grumari, of Barra da Tijuca AR. A single case, a two-year-old female, was reported in 1997 from the neighborhood of Santa Cruz, in Santa Cruz AR, PA-5, but far from the abovementioned known foci (Figure 1 and Table 1). The last two cases in Rio de Janeiro occurred in 2006 in the neighborhoods of Gericinó and Campo Grande. No cases of VL were reported in 2007 or 2008 (Figure 1).

The Pedra Branca and Gericinó massifs, which are part of the slopes of the Serra do Mar mountain range, located in the center of the municipality of Rio de Janeiro between $22^{\circ} 45^{\prime}$ and $23^{\circ} 05^{\prime}$ south latitude and $43^{\circ} 06^{\prime}$ and $43^{\circ} 47^{\prime}$ west longitude, form a mountain complex consisting of granite and gneiss rock that reaches its highest point at Pedra Branca peak $(1,024 \mathrm{~m})$, followed by Gericinó peak $(867 \mathrm{~m})$. The prevailing climate on the northern and northwestern slopes, which receive the most sunlight, is tropical wet (Aw type), with a mean annual temperature of $27.7^{\circ} \mathrm{C}$. The total annual rainfall is more than $1,400 \mathrm{~mm}$, with less than 60 $\mathrm{mm}$ in the driest months (July and August), with variable relative humidity of around $75 \%$. On the Atlantic slope, where the moisture from the ocean strikes a barrier on the mountainside, leading to constant rain at the base, the prevailing climate is wet (type Am) in the lowlands and rainy (type Af) on the slopes ${ }^{41}$. 


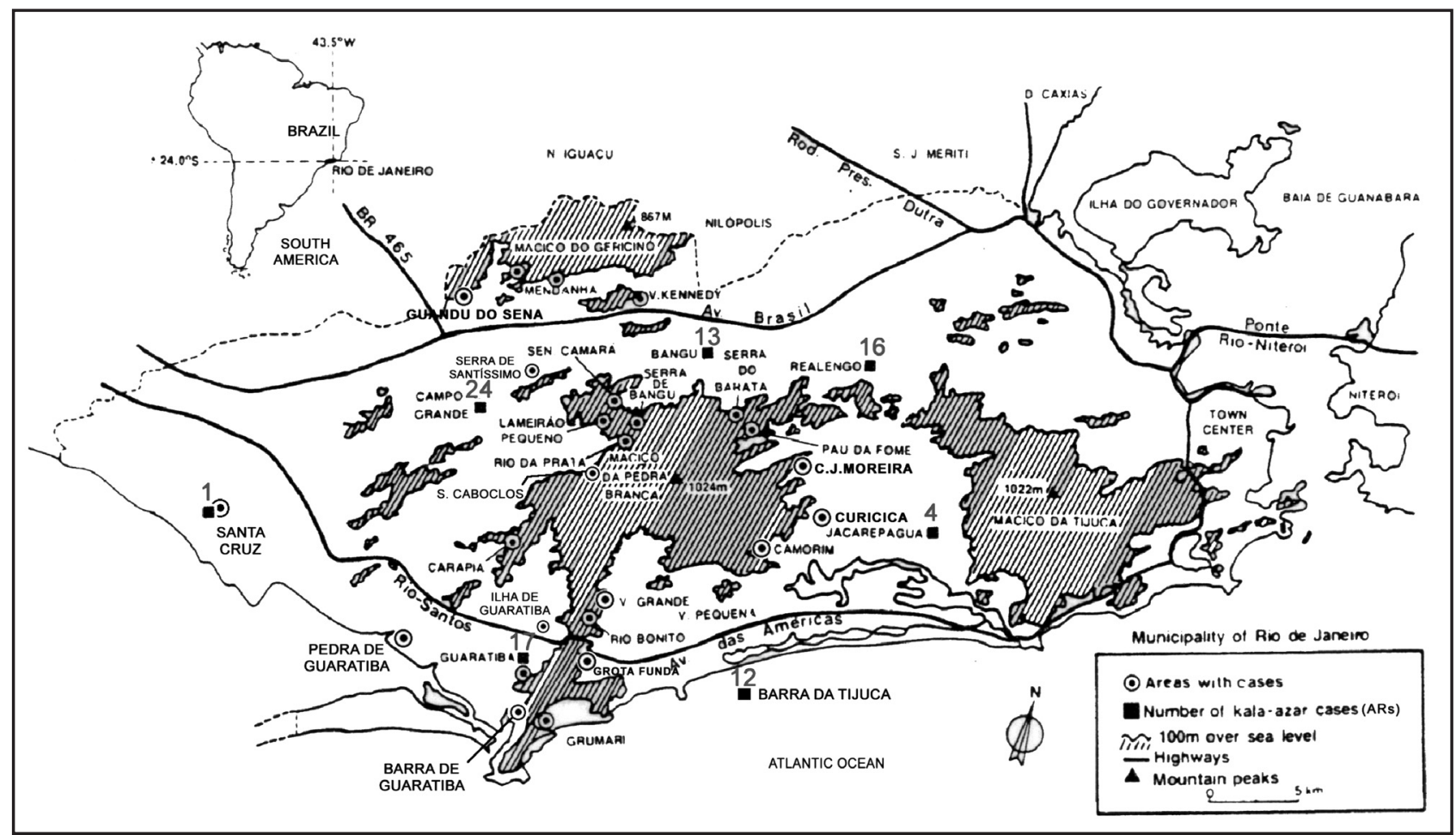

FIGURE 1

Distribution of autochthonous human cases of visceral leishmaniasis. Municipality of Rio de Janeiro, 1977-2008.

The Pedra Branca massif, covering an area of $152.1 \mathrm{~km}^{2}$, is home to the Pedra Branca State Park, which contains the largest proportions of surviving forest in the municipality and appears to act as an ecological barrier, with its Atlantic slopes facing the neighborhoods of Campo Grande (PA-5) and Barra da Tijuca and Jacarepaguá (PA-4). In the last of these, tegumentary leishmaniasis (TL) has occurred for some time, displaying sporadic outbreaks, with Leishmania (Viannia) braziliensis as the etiological agent $^{172430}$. Lutzomyia intermedia is the probable vector, based on its high density and because it has been found to be naturally infected $^{3744}$ and to be responsible for biting individuals inside their homes ${ }^{15}$.

In these neighborhoods, the areas most affected by both VL and TL were and still are periurban, with predominantly rural characteristics, usually hillsides close to or bordering on environmentally protected areas. The population was initially lowincome, living in precarious housing with no sewage or electricity, but after living in the area for decades ${ }^{30}$, the original population has been replaced more recently by new middle-class contingents living on family plots and in recently developed housing projects and gated communities.

In chronological order, VL cases began in 1977 on the Pedra Branca massif, in the Bangu neighborhood, and spread to Realengo and Campo Grande, but distributed unevenly in discontinuous foci. Beginning in 1982, cases were reported in Barra da Tijuca AR in the neighborhoods of Camorim, Vargem Grande and Grumari, in the locations known as Rio Bonito, Grumari and Piabas. Beginning in 1985, with an increase in cases until 1996, the disease spread to Guaratiba AR, in the neighborhoods of Barra de Guaratiba and Guaratiba, to Barra da Tijuca AR, in the Barra da Tijuca neighborhood, in the locations known as Grota Funda and Rio Bonito, and in the neighborhoods of Camorim, Vargem Grande and Grumari, and to Jacarepaguá AR, in the neighborhoods of Taquara and Curicica. There was a sharp decline in 1996. Meanwhile, between 1984 and 2006, the eight cases from the Gericinó massif were concentrated in the period from 1984 to 1989, with one case per year (Figure 2 and Table 1).

Thus, the series of cases that began on the continental slopes of the Pedra Branca massif gave way to a progression (and predominance) of cases on the coastal slope on the same massif, where the disease persisted, although declining from 1997 onwards, with an average of less than one case per year (Figure 3).

Regarding tegumentary leishmaniasis (TL), the disease had already been endemic in this region since the early $20^{\text {th }}$ century. In the 1970s, outbreaks began to occur in Barra da Tijuca and Jacarepaguá ARs. Thus, since 1974, the highest proportion of cases was observed in locations on the slopes and at the foot of the Pedra Branca massif (161 cases). From 1978 to 1980, the locations of Grumari, Piabas and Pau da Fome, in Barra da Tijuca and Jacarepaguá ARs, accounted for the majority of cases (73), with the disease extending to Campo Grande and Guaratiba (38 cases). From 1981 to 1984, areas in Campo Grande were heavily affected (99 cases), along with locations in Barra da Tijuca and Jacarepaguá ARs (202 cases). Meanwhile, on the northern 
TABLE 1

Origin of cases of visceral leishmaniasis in Rio de Janeiro by neighborhood, location, and massif (1977-2008).

\begin{tabular}{|c|c|c|c|c|c|}
\hline \multirow[t]{2}{*}{ Massif/Administrative region } & \multirow[t]{2}{*}{ Neighborhood } & \multirow[t]{2}{*}{ Location } & \multicolumn{2}{|c|}{ Cases } & \multirow{2}{*}{$\begin{array}{c}\text { Deaths } \\
\mathrm{n}\end{array}$} \\
\hline & & & $\mathrm{n}$ & $\%$ & \\
\hline Pedra Branca Massif & & & 79 & 90.8 & 8 \\
\hline \multirow[t]{4}{*}{ Bangu } & Bangu & Bangu & 2 & 2.3 & 1 \\
\hline & & Rio da Prata & 1 & 1.2 & 1 \\
\hline & & Serra do Viegas & 1 & 1.2 & 0 \\
\hline & Senador Camará & Serra do Lameirão & 1 & 1.2 & 0 \\
\hline \multirow[t]{2}{*}{ Realengo } & Realengo & Barata & 15 & 17.2 & 0 \\
\hline & & Realengo & $1^{*}$ & 1.2 & 0 \\
\hline \multirow[t]{3}{*}{ Campo Grande } & Campo Grande & Rio da Prata & 20 & 22.9 & 2 \\
\hline & & Serra de Santíssimo & 1 & 1.2 & 1 \\
\hline & & Serra dos Caboclos & 3 & 3.5 & 1 \\
\hline \multirow[t]{5}{*}{ Guaratiba } & Guaratiba & Carapiá & 2 & 2.3 & 0 \\
\hline & & Guaratiba & $1 *$ & 1.2 & 0 \\
\hline & & Ilha de Guaratiba & 2 & 2.3 & 0 \\
\hline & Barra de Guaratiba & Barra de Guaratiba & 11 & 12.6 & 0 \\
\hline & Pedra de Guaratiba & Pedra de Guaratiba & 1 & 1.2 & 0 \\
\hline \multirow[t]{5}{*}{ Barra Da Tijuca } & Barra da Tijuca & Grota Funda & 2 & 2.3 & 0 \\
\hline & & Rio Bonito & 2 & 2.3 & 2 \\
\hline & Grumari & Grumari/Piabas & 5 & 5.7 & 0 \\
\hline & Vargem Grande & Vargem Grande & 1 & 1.2 & 0 \\
\hline & Camorim & Camorim & 2 & 2.3 & 0 \\
\hline \multirow[t]{2}{*}{ Jacarepaguá } & Curicica & Colônia J. Moreira & 2 & 2.3 & 0 \\
\hline & Taquara & Pau da Fome & 2 & 2.3 & 0 \\
\hline Santa Cruz & Santa Cruz & Santa Cruz & 1 & 1.2 & 0 \\
\hline Gericinó Massif & & & 8 & 9.2 & 1 \\
\hline \multirow[t]{3}{*}{ Bangu } & & Guandu do Sena & 4 & 4.6 & 0 \\
\hline & Gericinó & Mendanha & 1 & 1.2 & 0 \\
\hline & & Vila Kennedy & 3 & 3.5 & 1 \\
\hline
\end{tabular}

* Leishmania/HIV co-infection.

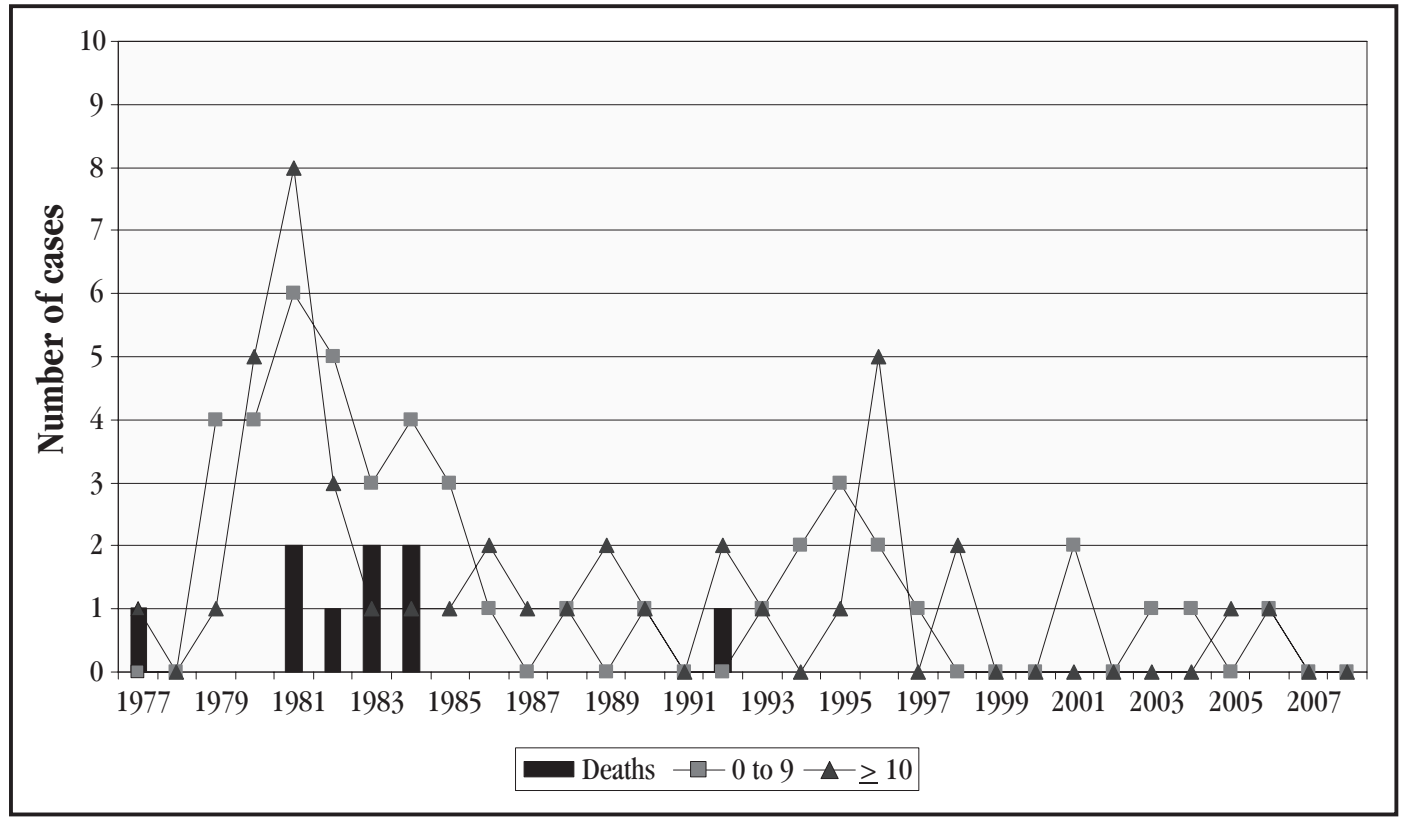

FIGURE 2

Cases and deaths from visceral leishmaniasis. according to patient's age (0 to 9 and e" 10 years old) and year of diagnosis. Municipality of Rio de Janeiro, 1977-2008. 


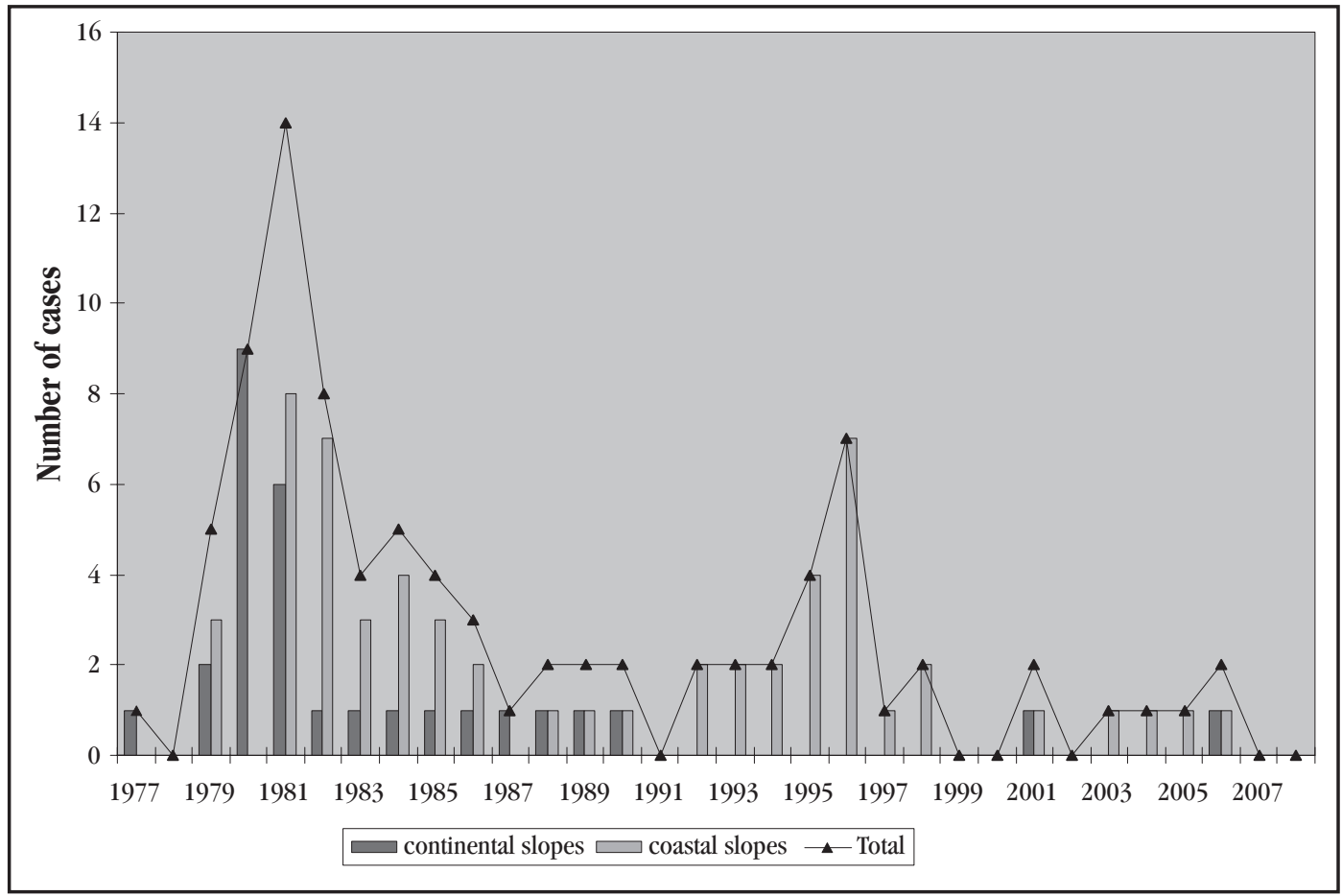

FIGURE 3

Historical series of cases of human visceral leishmaniasis by year of diagnosis and slopes (continental and coastal) where cases were detected. Municipality of Rio de Janeiro, Brazil, 1977-2008.

continental slopes of the same massif, where VL started, TL cases were more rare, with more cases beginning in 1981, namely 30 from 1981 to $1988^{13}$.

Thus, as if in a pendular movement, TL alternately precedes or succeeds VL, although the former has predominated on the wetter coastal slopes, where different studies have shown a higher population of Lutzomyia intermedia, the most likely vector of $\mathrm{TL}^{4452}$.

The age distribution of VL cases from the sites on the continental slope ( 29 cases) showed that $58.6 \%$ were 14 years of age or younger and $41.4 \%$ were older. On the other hand, on the coastal slopes (58 cases), where TL also occurs, and $70.7 \%$ of the VL cases were among patients aged 14 years or younger and $29.3 \%$ among patients aged 15 years or older (Table 2). There was an overall predominance of male patients (65.5\%), increasing progressively with age. The proportions were similar in the 14-and-under group: $33.7 \%$ and $31 \%$ of all cases, respectively, were males and females from this age group. Starting at 15 years, the disease was rare in females ( $10 \%$ of cases). Overall, the occurrence of only $34.5 \%$ of cases among patients aged four years and under and $65.5 \%$ among patients aged five years and older supports the theory of recent establishment of the endemic disease (Table 2), especially because of its initial predominance in adults, which gradually decreased. Until 1983 , only $25.7 \%$ of the patients were four years of age or younger, compared with $74.3 \%$ older than 5 years of age ${ }^{30}$ (Table 2).

The fatality rate among the 87 cases was $10.4 \%: 10.7 \%$ up to 14 years of age ( 6 deaths/56 cases) and $9.7 \%$ above 14 years of age (3/31). Between August 1977 (index case of death) and December 2006, eight deaths occurred between 1981 and 1984,

TABLE 2

Distribution of human visceral leishmaniasis cases by age and gender on the continental and coastal slopes of the Pedra Branca and Gericinó Massifs. Municipality of Rio de Janeiro, Brazil (1977-2008).

\begin{tabular}{|c|c|c|c|c|c|c|c|c|c|c|}
\hline \multirow{3}{*}{$\begin{array}{l}\text { Age Group } \\
\text { (years) }\end{array}$} & \multicolumn{4}{|c|}{ Slopes } & \multicolumn{4}{|c|}{ Patient Gender } & & \\
\hline & \multicolumn{2}{|c|}{ Continental } & \multicolumn{2}{|c|}{ Coastal } & \multicolumn{2}{|c|}{ Male } & \multicolumn{2}{|c|}{ Female } & \multicolumn{2}{|c|}{ Total } \\
\hline & $\mathrm{n}$ & $\%$ & $\mathrm{n}$ & $\%$ & $\mathrm{n}$ & $\%$ & $\mathrm{n}$ & $\%$ & $\mathrm{n}$ & $\%$ \\
\hline 0 to 4 & 6 & 6.9 & 24 & 27.6 & 16 & 18.4 & 14 & 16.0 & 30 & 34.5 \\
\hline 5 to 9 & 5 & 5.8 & 11 & 12.6 & 6 & 6.9 & 10 & 11.5 & 16 & 18.4 \\
\hline 10 to 14 & 4 & 4.6 & 6 & 6.9 & 7 & 8.0 & 3 & 3.4 & 10 & 11.5 \\
\hline 15 to 19 & 4 & 4.6 & 3 & 3.5 & 7 & 8.0 & - & 0.0 & 7 & 8.1 \\
\hline 20 to 39 & 7 & 8.0 & 8 & 9.2 & 13 & 14.9 & 2 & 2.3 & 15 & 17.2 \\
\hline$\geq 40$ & 3 & 3.5 & 6 & 6.9 & 8 & 9.2 & 1 & 1.4 & 9 & 10.3 \\
\hline Total & 29 & 33.3 & 58 & 66.7 & 57 & 65.5 & 30 & 34.5 & 87 & 100.0 \\
\hline
\end{tabular}


while only one death occurred later, in 1992. Out of the total of nine deaths, seven were concentrated from 1981 to 1984, when the fatality rate was 22.6\%. The first death occurred in 1977 and the last in 1992.

The temporal distribution of human cases according to date of diagnosis showed that the highest frequency was between the months of May and November, with the median in August. If it is assumed that the incubation period plus the period of the disease prior to diagnosis totals approximately six months, the infections probably occurred mainly between the months of November and March, i.e. the hottest months of the year and the ones with the highest rainfall ${ }^{30}$.

\section{HUMAN CASES}

We participated in the clinical care for patients admitted to the Department of Infectious and Parasitic Diseases at the Clementino Fraga Filho University Hospital of the Federal University of Rio de Janeiro. In 23 out of 24 patients, Leishmania was detected in bone marrow samples, and in 12 out of 19, Leishmania chagasi was isolated in the culture medium ${ }^{30}$.

All the patients tested positive for the IgG class using indirect immunofluorescence (IIF), with titers ranging from 1:90 to $1: 2,800$, and there was a tendency for the values to remain high for more than six months ${ }^{25}$. Regarding the IgM classes, we observed specific IgM antibodies in $35.7 \%{ }^{30}$.

As of 2007, only two autochthonous cases of VL associated with acquired immunodeficiency syndrome (AIDS) had been detected. The first was diagnosed in August 1990 and was a 23-year-old female patient living in Realengo, and the second was in September 2005 and was a 32-year-old male patient (IV drug user) from Guaratiba.

In all 87 cases, the autochthonous origin was confirmed by interviews with the patients. Without exception, etiological confirmation of the clinical diagnosis was obtained for these patients (demonstration and/or isolation of Leishmania by means of bone marrow aspiration and/or positive indirect immunofluorescence with high titers).

\section{EPIDEMIOLOGICAL STUDIES}

Humans. Following the occurrence of 11 cases of $\mathrm{VL}$ in a single location without TL, at Serra do Barata in Realengo, on the northern continental slope of the Pedra Branca massif, a clinical and epidemiological survey was conducted, including an active patient search. In addition to patient histories and physical examinations, blood samples were drawn from the 121 residents for IIF and DHST, not counting the 11 previously diagnosed cases of VL. This survey detected one symptomatic case with subsequent parasitological confirmation, one subclinical case (with no signs or symptoms) with positive IIF and DHST but without parasitological confirmation and three individuals (two adults and one child) with positive DHST alone ${ }^{30}$.
Later, the same type of survey was conducted in the district of Campo Grande, at the location known as Rio da Prata, on the western slope of the same massif, in two distinct communities: one (239 individuals) that was a recent squatter settlement where cases of VL had begun to occur, and another (with 146 individuals) that was an older settlement where cases of TL had occurred. In the area with VL, there were positive DHST results in all age brackets, ranging from $9.4 \%$ to $14.6 \%$, with a mean of $11 \%$, while in the area with TL, the DHST-positive rate increased with age, ranging from $16.1 \%$ to $63.6 \%$, with a mean of $32.2 \%{ }^{54}$.

As part of the same survey, a new active search for human and canine cases was conducted in the area with VL, including clinical and serological examinations (IIF), regardless of clinical manifestations. As a result, 75 residents were classified into four groups of dwellings according to risk, based on detection (or lack thereof) of seropositive human and canine cases. In Group I, with human cases only, the IIF rate among family members was zero and DHST was 10\%; in Group II, with canine cases only, IIF was $10.3 \%$ and DHST 13.8\%; in Group III, with both human and canine cases, IIF was $15.4 \%$ and DHST $23.1 \%$; and in Group IV, with neither human nor canine cases, IIF was zero and DHST was $3.9 \%{ }^{30}$. In groups II and III, the presence of seven clinically normal individuals (with no signs or symptoms), but who were IIF and DHST-positive, represented $9.9 \%$ of the population examined, thus suggesting that there were occurrences of subclinical forms of $\mathrm{VL}^{55}$.

Subclinical or unapparent infections do not appear to be rare, and they probably play an important role in the epidemiology of kala-azar, not only as a likely source of infection, but also representing the proportion of individuals who are immune to the disease. Meanwhile, if these same individuals were to undergo subsequent immunosuppression, they could develop the clinical form of $\mathrm{VL}^{3422} 2627$.

Visceral leishmaniasis in Rio de Janeiro, which began with an outbreak located on the continental slopes, with frequent occurrence among adults and without the presence of tegumentary leishmaniasis, then spread to the coastal slopes, where human tegumentary leishmaniasis was already occurring, with circulation of Leishmania (Viannia) braziliensis. This could explain the higher incidence of VL in children on the coastal slopes ever since the disease first appeared in the area, thus suggesting that immune cross-protection was occurring among older age groups because of the longer history of TL in the area ${ }^{24}$ and the more recent appearance of $\mathrm{VL}^{29}$.

Likewise, the historical series of VL outbreaks shows a decline in incidence among older age groups (Table 2), probably due to depletion of susceptible individuals among older people, associated with the development of immunity through progressive lifetime exposure to natural infections, and possibly also greater resistance among these groups due to cross-protection in areas with preexisting TL, among other factors. In parallel, increased transmission in dogs would have increased the risk of transmission especially in the younger population, due to the greater abundance of sources of infection in the household and the tendency towards greater contact between children and these 
pets, along with children's greater natural susceptibility, due to their lack of acquired immunity and the low nutritional standards of poor populations ${ }^{329}$

A prospective study was carried out on the clinical, immunological, epidemiological and social characteristics of 30 former patients who had been treated for and cured of VL, among autochthonous cases reported between 1977 and 1993, compared with members of their household and neighbors. The study concluded that the former patients presented residual infection and/or probable immunity: $60.7 \%$ found to be positive using DHST $(17 / 28)$; $31 \%$ positive using IIF (9/29); and $32 \%$ positive using ELISA (8/25). This suggested that persistent parasitism in the former patients was possible, with the potential for: a) relapse in the event of decreased immunity; b) transmission of VL through blood donation, intravenous drug use or organ donation; and c) a role as a source of infection for sandflies ${ }^{22}$.

Curiously, in Campo Grande, on the western slope, one case of concurrent visceral and tegumentary human infection was detected, in a five-year-old boy with a prior history suggestive of kala-azar. Subsequently, before receiving treatment, this boy developed an ulcerated skin lesion (coinciding with the appearance of a similar lesion in a sister). A biopsy on the skin lesion and bone marrow aspirate showed parasites that were identified as Leishmania braziliensis and Leishmania chagasi, respectively ${ }^{34}$. From another patient living in the same area, an adult male who only presented an ulcerated skin lesion, Leishmania chagasi was isolated from that lesion ${ }^{33}$.

A 35-year-old male patient from the Jacarepaguá AR (an endemic area for TL with cases of $\mathrm{VL}$ ), who presented signs suggestive of VL and HIV coinfection, underwent a bone marrow biopsy that showed amastigote forms and positive culturing, with a trypanosomatid characterized as Leptomonas pulexsimulantis, a dog flea parasite ${ }^{35}$. This patient was not reported as a VL case.

Reservoirs. Beginning in 1977, after a human case of VL was found on the slopes of Serra de Bangu, with proof that the case was autochthonous and that $97.9 \%$ of the phlebotomine sandflies captured above 100 meters altitude were Lutzomyia longipalpis, several canine surveys were conducted. There was initial difficulty in detecting seropositive $\operatorname{dog} s^{23}$.

In 1980, the Brazilian Ministry of Health conducted a canine survey in areas with new human cases (Realengo, Bangu and Serra do Lameirão - Senador Camará). Out of the 526 symptomatic and asymptomatic dogs examined, 10 (1.9\%) were seropositive to the complement fixation reaction (CF) and negative to slide apposition, and $10(1.9 \%)$ were positive to direct examination and negative to CF. Among the CF-positive dogs, five were taken to the laboratory; in all five, even those that were clinically normal, Leishmania was found in tissues, and the parasite was cultured from both viscera and apparently normal skin ${ }^{23}{ }^{26}$. A similar observation was made in skin samples taken from 14 dogs with Leishmania chagasi alone, all from the same area, of which seven were symptomatic and seven were asymptomatic ${ }^{18}$.

In 1982-83, ear skin samples were taken for slide apposition, along with filter paper blood samples, to investigate antiLeishmania antibodies by means of IIF. A total of 1,342 dogs were examined; $4.3 \%$ of them were IIF-positive and came from areas with VL alone: Realengo, Bangu and Senador Câmara 9 . New surveys were conducted after findings of new human cases on the coastal slopes of the same massif (Campo Grande and Jacarepaguá Administrative Regions), where TL had already been reported ${ }^{15}$.

A canine serological survey from 1984 to 1989 using IIF on 22,828 dogs demonstrated that animals from areas with VL alone (Realengo, Bangu and Senador Camará) showed a decline in seroprevalence from $4.3 \%$ to $0.4 \%$. The seroprevalence in dogs from an area with both VL and TL (Campo Grande) decreased from $12.7 \%$ to $0.6 \%$. Meanwhile, in the area known as Pau da Fome in the Jacarepaguá AR (southeastern coastal slope of the Pedra Branca massif), where only human and canine TL cases had been reported, the canine seroprevalence decreased from $8.6 \%$ to $1.8 \%{ }^{32}$.

These decreases generally appear to confirm that the prophylactic measures taken in these areas were effective: culling of infected dogs, active search for and treatment of human cases, and spraying of houses and outbuildings with insecticides, regardless of whether VL and TL occurred singly or together.

A recent parasitological investigation was performed on 66 Leishmania seroreactive dogs captured during VL control activities. Leishmania was isolated from $80.3 \%$ of the animals: 12 (22.6\%) showed Leishmania (Viannia) braziliensis exclusively from the skin lesions; 39 (73.6\%) showed Leishmania (Leishmania) chagasi from different sites in the same animal; and two (3.8\%), showed isolates of both Leishmania (Viannia) braziliensis from the skin lesions and Leishmania (Leishmania) chagas $i$ from different sites, respectively ${ }^{19}$. These findings confirm that coinfection with Leishmania (Viannia) braziliensis and Leishmania (Leishmania) chagasi can occur. The existence of Leishmania braziliensis infection and mixed infections in dogs from an area with human VL indicates that the Leishmania species involved needs to be identified, in order to enhance the surveillance and control measures ${ }^{19}$. In addition, studies need to be conducted on the therapeutic response among dogs with skin lesions involving Leishmania brasiliensis: intralesional treatment with antimonial agents has been found to be promising ${ }^{6}$.

Attempts to treat dogs that were seropositive for Leishmania chagas $i$, with $100 \mathrm{mg} / \mathrm{kg} /$ day of antimonial agents intramuscularly in two 17-day series, were either unsuccessful or were actually associated with worsening of the disease ${ }^{23}$.

Canine leishmaniasis appears to have emerged almost simultaneously with the human disease, given the initial difficulties in detecting infected animals between 1977 and 1979 and the relative frequency of infected dogs from 1980 onwards, as shown by the canine surveys, notwithstanding their methodological variations $^{23}$. In Senador Camará, where canine infection existed, only one human case was identified.

In general, no clear relationship has been observed between the presence and intensity of clinical signs in dogs and the detection of parasites in viscera and/or normal skin. The highest IIF titers occurred in dogs with concurrent visceral involvement and presence of Leishmania in the skin ${ }^{26}$. 
Although canine seroprevalence depends on ecological and social factors and the types of surveys used, it varies greatly in endemic areas, and there is no consensus on the relationship between its magnitude and the risk of occurrence of human disease ${ }^{8}$.

Nevertheless, the evidence of wide dispersal of the canine enzootic disease starting from an initial focus (Bangu) and the high proportion of asymptomatic infected dogs, plus the ineffectiveness of treatments for dogs, appear to prove that serological and parasitological surveys are important for epidemiological diagnosis. Through this, the various control measures can be reevaluated. These measures should include culling all positive dogs, an approach that has coincided with decreased occurrence of human cases in the controlled areas in Rio de Janeiro, together with vector control.

However, these measures could undergo major changes if canine birth control were to be implemented and an effective vaccine were used against canine leishmaniasis, which could be administered together with annual rabies vaccinations in highrisk $\operatorname{areas}^{23}$.

The Leishmania samples isolated from both human and canine cases of VL that were characterized biochemically as Leishmania chagasi showed a high degree of homogeneity. The same was found regarding Leishmania braziliensis samples from human and canine TL cases ${ }^{17} 193136$.

Attempts to find wild animals that serve as possible Leishmania reservoirs have been fruitless ${ }^{27} 54$, although the synanthropic opossum Didelphis marsupialis was found infected with Leishmania in Guaratiba? .

Vectors. At the time of the first recorded autochthonous cases of VL, the predominant phlebotomine fauna on the northern continental slope was Lutzomyia longipalpis (97.9\%), at altitudes above $100 \mathrm{~m}$, while Lutzomyia intermedia predominated below $100 \mathrm{~m}$. On the western coastal slope, where TL cases were also reported, Lutzomyia intermedia accounted for $82.4 \%$ of the sandfly fauna and Lutzomyia longipalpis 4.6\%. On the southern coastal slope, where only TL was detected, the prevailing species was Lutzomyia intermedia, accounting for $92.6 \%{ }^{150}$.

Meanwhile, in the ARs in the lowlands of Barra da Tijuca, Jacarepaguá and Guaratiba, where 31 (35.6\%) cases of VL were reported, and at the sites in Gericinó with eight (9.2\%) cases, Lutzomyia intermedia has been the predominant sandfly species, while Lutzomyia longipalpis has been less frequent ${ }^{45} 51$. In 18,303 sandflies captured on the southern coastal slopes of the Pedra Branca massif, Souza et $\mathrm{al}^{51}$ found that $87.3 \%$ were Lutzomyia intermedia, 6.6\% Lutzomyia migonei, 3.1\% Lutzomyia longipalpis and $1.9 \%$ Lutzomyia firmatoi. Although Lutzomyia longipalpis predominated in Barra de Guaratiba, accounting for $46.8 \%$ of the fauna, it was absent in six other locations with cases of VL and where Lutzomyia migonei and Lutzomyia firmato $i$ were detected (Mendanha, Carapiá, Ilha de Guaratiba, Grumari, Camorim and Colônia Juliano Moreira). Since Lutzomyia migone $i$ is known for its strong cynophilia ${ }^{15}$, it might contribute towards maintaining and expanding canine infection ${ }^{28}$. Interestingly, the areas studied showed a higher proportion of male specimens in the species Lutzomyia intermedia, Lutzomyia migonei, Lutzomyia longipalpis and Lutzomyia cortellezzii, thus revealing the existence of breeding sites near the peridomestic capture points.

\section{ENVIRONMENTAL FACTORS}

Despite the large body of accumulated data, there is still a lack of studies involving the more precise identification of environmental, human, social and economic factors, among others, that may have influenced the establishment and spread of visceral leishmaniasis in periurban areas in the city of Rio de Janeiro. While TL has been known in Rio de Janeiro since the early $20^{\text {th }}$ century, VL was not identified there until the late 1970 s. The climate changes caused by urbanization and global warming, with extreme events in local microclimates ${ }^{12}$, may be playing a relevant role in increasing and expanding the presence of insect vectors for leishmaniasis.

Deforestation in Rio de Janeiro dates back to the $16^{\text {th }}$ century, with the allocation of the sesmarias (colonial land grants) and the early sugarcane plantations. The coffee-growing economic cycle, beginning in the early $19^{\text {th }}$ century, led to occupation of the slopes on the Pedra Branca massif up to $200 \mathrm{~m}$ above sea level, and was replaced by fruit orchards in the early $20^{\text {th }}$ century, with orange-growing beginning in 1930, while coffee-growing moving to the Paraíba valley. After the decline in citrus fruit exports in the years preceding World War II, large areas were redeployed for banana-growing, which steadily encroached ever higher up the slopes, reaching altitudes of more than $500 \mathrm{~m}$ in some areas. These banana plantations have remained to this day, although land higher than $100 \mathrm{~m}$ above sea level is now legally off limits and subject to environmental protection ${ }^{41}$.

In the 1940s and 1950s, the neighborhood of Campo Grande, with its mixture of urban and rural characteristics, had one of Rio's highest population growth rates. The same was true for the Jacarepaguá, Barra da Tijuca and Guaratiba ARs in the 1970s and 1980s, when large populations were attracted to new housing developments, a process that is still continuing ${ }^{13}$.

However, in the areas close to the massif, far from the main roads and railways, the conditions in the settlements on the mountainsides have remained virtually unchanged for decades, on the slopes in Campo Grande, Jacarepaguá and Guaratiba. This has creating a kind of rural-urban fringe with persistent areas of plant cover and residual subsistence farming by poor families ${ }^{13}$. Meanwhile, below $100 \mathrm{~m}$, the plantations gave way to occupation by the working class in search of work opportunities in the vicinity, as well as housing developments and weekend acreages for the middle and upper class, associated with increases in sandfly populations in peridomestic environments. The growth in sandfly populations resulting from the arrival of human population groups susceptible to TL in these areas favored transmission of leishmaniasis in foci with differentiated risks, depending on the topography and the population density near the access points to mass transportation ${ }^{13}$. 
By using satellite-based remote sensing data from the Landsat multispectral scanner to determine the deforestation rate, it was found that the area of deforestation above the altitude of $100 \mathrm{~m}$ in the municipality of Rio de Janeiro increased by $10.4 \%$ between 1972 and 1978. This was interpreted as the consequence of inappropriate land use on the Pedra Branca, Tijuca, and Gericinó massifs, even though federal and municipal legislation set requirements for conservation and maintenance of plant cover on the slopes above $100 \mathrm{~m}$, i.e. the surviving areas of the Atlantic Forest, as an environmental preservation area ${ }^{41}$. The years between 1984 and 2001 witnessed a $14.9 \%$ reduction in the city's natural forest cover, predominantly on the coastal slopes of the Pedra Branca massif, in PA- 4 and PA- $5{ }^{43}$.

Urban land use has continued to encroach on these areas. From 1984 to 2001, the urbanized area of the city increased by 9,468 hectares. PA- 4 showed an increase of $41 \%$ in the urbanization of its territory, followed by PA-5, with 35\%. Together, these two accounted for $82 \%$ of the total increase in urbanization in the municipality ${ }^{43}$.

Importantly, from 1972 to 1979 , coinciding with the first cases of VL, lengthwise deforestation cut across the forest reserve on the Pedra Branca massif from east to west, from the Furnas power station at Pau da Fome, Jacarepaguá, on the eastern slope, to Rio da Prata, Campo Grande, on the western slope, in order to install high-voltage overhead power lines. Various Brazilian construction companies participated in this project, recruiting labor from various places, including northeastern Brazil, and kept the workers living on-site in mobile camps along the power-line right-of-way ${ }^{30}$.

Thus, starting from this area, the introduction of men and/or their dogs carrying the parasite from other endemic regions of the country could explain the appearance of this southernmost and most locally circumscribed focus of visceral leishmaniasis in Brazil, associated with the presence of Lutzomyia longipalpis and canine infection.

\section{CONTROL MEASURES}

Despite the small number of cases of human kala-azar in Rio de Janeiro, the incidence rate in the high-risk areas (with a population of approximately 500,000) reached 2.8 per 100,000 inhabitants in 1981 (Campo Grande), decreasing steadily with the subsequent control measures. The overall mean disease rate from 1977 to 1983 was 0.4 per 100,000 inhabitants in the risk areas, decreasing to less than 0.01 per 100,000 inhabitants since 1997. Similar results were found in the only successful visceral leishmaniasis control campaign in Brazil, in the Rio Doce valley ${ }^{20}$, Minas Gerais, using the classical control measures that were also adopted in Rio de Janeiro thereafter.

From 2000 to 2004, 114,576 dogs were examined. From 94,845 of these, filter paper blood eluates were drawn for IIF screening and $0.6 \%$ of these were found to be positive. Among the positive dogs, total serum samples were taken for retesting with quantitative IIF, giving a confirmed positive test rate of only
$0.2 \%$. The mean number of dogs surveyed was 2.4 per household, which were predominantly young animals because of continuous replenishment of pet animals by the human population (MV Andrade: unpublished data). In the first half-year of 2008, out of 11,877 dogs examined, $193(1.6 \%)$ were positive according to the eluate test, of which 177 (1.5\%) were confirmed by retesting (MV Andrade: unpublished data). The current juxtaposition of canine VL and TL in most of the areas under surveillance, and the possibility of natural infection with other trypanosomatids, may be overestimating the serological results because of cross-reactions between the tests.

In 2003, a project was implemented to monitor leishmaniasis vectors (VL and TL) in all of the 31 areas, with notification of autochthonous human and canine cases. Monthly manual captures were performed in areas surrounding homes and outbuildings, from 6:00 pm to 10:00 pm (four hours of capture/area/man) ) $^{52}$.

In areas where cases of human or canine VL were detected, traditional control measures were conducted beginning in 1979, initially by the Ministry of Health, and subsequently by the municipality of Rio de Janeiro, following decentralization of activities within the Brazilian National Health System ${ }^{42}{ }^{49}$. These measures included: active searching of human patients and dogs in the target areas, with referral, diagnosis and treatment of human cases; serological surveys on the dog population with culling of asymptomatic or symptomatic seropositive animals; entomological surveys and species identification, followed by four-monthly insecticide spraying of all the houses and outbuildings, over a radius of $100 \mathrm{~m}$ from each home with a reported human or canine case; and educational activities within the community.

However, even with these control measures, there was a shift of human and canine cases to new areas in the late 1980s and early 1990s, towards the southeastern and southwestern coastal slopes of the Pedra Branca massif (Jacarepaguá, Barra da Tijuca and Guaratiba ARs). This shift triggered new preventive interventions that appear to have controlled this expansion process.

Despite the relatively low incidence of leishmaniasis in the municipality of Rio de Janeiro, compared with regions in other endemic states and municipalities in Brazil, vector monitoring has contributed towards identifying epidemiologically important species for leishmaniasis transmission. This monitoring has thus supported the control strategy and the resulting decrease in the incidence of these diseases.

Until $2007,80 \%$ of houses and outbuildings were sprayed with pyrethroid insecticide (cypermethrin $125 \mathrm{mg} / \mathrm{m}^{2}$ in the areas with the highest percentages of Lutzomyia longipalpis). However, this approach was halted in 2008 based on a directive from the Ministry of Health that recommended keeping peridomestic areas clean and free from low-lying vegetation, plant debris, animals and garbage, in addition to environmental management with periodic changes in the positions of chicken coops and pigsties, located far from houses, using an annual rotation strategy. More recently, beginning in August 2008, culling of seropositive asymptomatic dogs was also suspended by the Rio de Janeiro Special Secretariat for Animal Protection and Defense. 
Strict maintenance of all these activities during 2007 by a team under the same coordinator and working directly in the areas with known cases of VL probably averted the expected increase in human and canine cases and contributed towards the steady reduction that has continued to the present day.

According to current Ministry of Health guidelines ${ }^{49}$, the municipality of Rio de Janeiro is classified as having sporadic VL transmission, and is required to conduct dog population surveys, active searches for dogs with a clinical suspicion of the disease, control of stray dogs, entomological surveys and environmental sanitation, but not chemical vector control with insecticides. Previously, the 12-month targets for the Municipal Health Department were to reach 45,000 households in VL transmission areas, examine 23,000 dogs, and spray 6,300 households (MV Andrade: unpublished data)

The fact that the periurban areas where VL has occurred have rural characteristics with focal transmission, where these measures are recommended, and that there is an overlapping of areas with TL, where chemical control against Lutzomyia intermedia has proven efficient ${ }^{17}$, justifies continuing the traditional control measures.

The continuity of measures by the Municipal Health Department, maintenance of health teams with experience in these activities and technical and scientific backing from research institutes within the Oswaldo Cruz Foundation (Fiocruz) to support the diagnosing of human and canine cases and train personnel in the Brazilian National Health System (SUS) regarding health surveillance and vector monitoring and control appear to have ensured the current situation of limited sporadic transmission in Rio de Janeiro and to have delayed the spread of human VL to other municipalities in the state.

\section{ACKNOWLEDGEMENTS}

The authors wish to thank the Rio de Janeiro Municipal Health Department and specifically Dr. Meri Baran, Superintendent of Health Surveillance, for providing epidemiological data, and Tatiana Vieira de Carvalho for secretarial assistance.

\section{REFERENCES}

1. Aguiar GM, Medeiros WM, Santos TG, Klein AFL, Ferreira V. Ecology of sandflies in a recent focus of cutaneous Leishmaniasis in Paraty, litoral of Rio de Janeiro state (Diptera, Psychodidae, Phlebotominae). Memórias do Instituto Oswaldo Cruz 88:339-340,1993.

2. Alencar JE. Calazar canino. Contribuição para o estudo da epidemiologia do calazar no Brasil. Tese de Doutorado, Universidade Federal do Ceará, Fortaleza, 1959.

3. Badaró R, Carvalho EM, Rocha H, Queiroz AC, Jones TC. Leishmania donovani: An opportunistic microbe associated with progressive disease in three immunocompromised patients. Lancet 1:647-649,1986a.

4. Badaró R, Jones TC, Carvalho EM, Sampaio D, Reed SG, Barral A, Teixeira R, Johnson Jr WD. New perspectives on a subclinical form of visceral leishmaniasis. Journal of Infectious Diseases 148:1003-1011, 1986b.

5. Barbosa GMS, Marzochi MCA, Massard CL, Santos GPL, Confort EM. Epidemiological aspects of canine american tegumentary leishmaniasis in the
Municipality of Paraty, State of Rio de Janeiro, Brazil. Cadernos de Saúde Pública 15: 641-646, 1999.

6. Barbosa-Santos EG, Marzochi MC, Conceição NF, Brito CM, Barroso JA, Pacheco RS. N-methilglucamine antimonate $(\mathrm{SbV}+)$ intralesional tegumentary leishmaniasis therapy. Parasite 5: 175-180, 1998.

7. Cabrera MAA, Marzochi MCA, Paula AA, Camacho AA, Xavier SC, Silva AV, Jansen AM. Canine Visceral leishmaniasis in Barra de Guaratiba, Rio de Janeiro, Brazil. Revista do Instituto de Medicina Tropical de São Paulo 45:79-83, 2003.

8. Costa CHN, Vieira JBF. Mudanças no controle da leishmaniose visceral no Brasil. Revista da Sociedade Brasileira de Medicina Tropical 34: 223-228, 2001.

9. Coutinho SG, Nunes MP, Marzochi MCA, Tramontano NC. A survey for american cutaneous and visceral leishmaniasis among 1342 dogs from areas in Rio de Janeiro (Brazil) where the human diseases occur. Memórias do Instituto Oswaldo Cruz 80:17-22, 1985.

10. Dantas-Torres F, Brandão Filho SP. Expansão geográfica da leishmaniose visceral no estado de Pernambuco. Revista da Sociedade Brasileira de Medicina Tropical 39:353-356, 2006.

11. Deane LM. Leishmaniose visceral no Brasil: estudos sobre reservatórios e transmissores realizados no Estado do Ceará. Rio de Janeiro, Serviço Nacional de Educação Sanitária. Tese de Doutorado, Universidade de São Paulo, São Paulo, SP, 1956.

12. Gusmão PP, Carmo PS, Vianna SB. Rio, o aquecimento global e a cidade, próximos 100 anos. Instituto Municipal de Urbanismo Pereira Passos, Rio de janeiro, 2008.

13. Kawa H, Sabroza PC. Espacialização da leishmaniose tegumentar na cidade do Rio de Janeiro. Cadernos de Saúde Pública 18:853-865, 2002.

14. Lainson R, Rangel EF. Lutzomyia longipalpis and the eco-epidemiology of American visceral leishmaniasis, with particular reference to Brazil: a review. Memórias do Instituto Oswaldo Cruz 100:811-827, 2005.

15. Lima LCR, Marzochi MCA, Sabroza PC. Flebotomíneos em área de ocorrência de leishmaniose tegumentar no bairro de Campo Grande, Rio de Janeiro, Brasil. Revista Brasileira de Malariologia e Doenças Tropicais 33: 64-74, 1981.

16. Lima LCR, Marzochi MCA, Sabroza PC, Souza MA. Observações sobre a leishmaniose tegumentar cinco anos após profilaxia. Revista de Saúde Pública 22:73-77, 1988.

17. Lopes UG, Momen H, Grimaldi Jr G, Marzochi MCA, Pacheco RS, Morel CM. Schizodeme and zymodeme characterization of Leishmania in the investigation of foci visceral and cutaneous leishmaniasis. Journal of Parasitololy 70: 89-98, 1984.

18. Madeira MF, Schubach AO, Schubach TMP, Leal CA, Marzochi MCA. Identification of Leishmania chagasi isolated from healthy skin symptomatic and asymptomatic dogs seropositive for leishmaniasis in the Municipality of Rio de Janeiro, Brazil. Brazilian Journal of Infectious Diseases 8:440-444, 2004.

19. Madeira MF, Schubach AO, Schubach TMP, Pereira SA, Figueiredo FB, Baptista C, Leal CA, Melo CX, Confort EM, Marzochi MCA. Post mortem evaluation of dogs seroreactive for Leishmania from Rio de Janeiro, Brazil. Veterinary Parasitology:138:366-370, 2006.

20. Magalhães PA, Mayring W, Costa CA, Melo MN, Dias M, Batista SM, Michalik MSM, Williams P. Calazar na zona do Vale do Rio Doce - Minas Gerais, resultado das medidas profiláticas. Revista do Instituto de Medicina Tropical de São Paulo 22:157-212, 1980

21. Marty P, Rosental E. Treatment of visceral leishmaniasis: a review of current treatment pratices. Expert Opinion Pharmacother 3: 1101-1108, 2002.

22. Marzochi KBF, Marzochi MCA, Silva VL, Carvalho RW, Souza MB, Gomes MZG, Souza MJFS, Andrade MV, Almeida DC. Prospective evaluation of human visceral leishmaniasis after treatment in Rio de Janeiro, 1977-1993. In: Brandão Filho S (ed). Research and control of human leishmaniasis in Brazil. Fundação Oswaldo Cruz, Recife, p.275-283, 1993.

23. Marzochi MCA, Coutinho SG, Sabroza PC, Souza MA, Souza PPM, Toledo L. Leishmaniose visceral canina no Rio de Janeiro - Brasil. Cadernos de Saúde Pública 1: 432-446, 1985b.

24. Marzochi MCA, Coutinho SG, Sabroza PC, Souza WJ. Reação de imunofluorescência indireta e intradermorreação para Leishmaniose Tegumentar Americana em moradores na área de Jacarepaguá (Rio de Janeiro): Estudo comparativo dos resultados observados em 1974 e 1978. Revista do Instituto de Medicina Tropical de São Paulo 22:149-155, 1980. 
25. Marzochi MCA, Coutinho SG, Souza WJ, Amendoeira MRR. Leishmaniose Visceral (Calazar). Jornal Brasileiro de Medicina 42:69-84, 1981.

26. Marzochi MCA, Coutinho SG, Souza WJS, Toledo LM, Grimaldi-Filho G, Momen H, Pacheco RS, Sabroza PC, Souza MA, Rangel-Filho FB, Tramontano NC. Canine visceral leishmaniasis in Rio de Janeiro, Brazil. Clinical, parasitological, therapeutic and epidemiological findings (1977-1983). 1986. Memórias do Instituto Oswaldo Cruz 80: 349-357, 1985c

27. Marzochi MCA, Marzochi KBF. Tegumentary and visceral leishmaniases in Brazil. Emerging anthropozoonosis and possibilities for their control. Cadernos de Saúde Pública 10 (Supl. 2):359-375, 1994

28. Marzochi MCA, Marzochi KBF. Leishmanioses em áreas urbanas. Revista da Sociedade Brasileira de Medicina Tropical 30 (supl 1):162-165, 1997.

29. Marzochi MCA, Marzochi KBF, Carvalho RW. Visceral leishmaniasis in Rio de Janeiro, Brazil. Parasitology Today 10:37-40, 1994

30. Marzochi MCA, Sabroza PC, Toledo LM, Tramontano NC, Marzochi KBF, Rangel-Filho F. Leishmaniose Visceral na cidade do Rio de Janeiro, Brasil. Cadernos de Saúde Pública 1:5-17, 1985a.

31. Momen H, Grimaldi Jr G, Marzochi MCA. Identification of New World Leishmania isolates by agarose gel electrophoresis and polyacrylamide gel isoelectrofocusing. Journal of Cellular Biochemistry 7A: 70:29, 1983.

32. Nunes MP, Jackson JM, Carvalho RW, Furtado NJ, Coutinho SG. Serological survey for canine cutaneous and visceral leishmaniasis in areas at risk for transmission in Rio de Janeiro where prophylactic measures had been adopted. Memórias do Instituto Oswaldo Cruz 86: 411-417, 1991.

33. Oliveira-Neto MP, Grimaldi Jr G, Momen H, Pacheco RS, Marzochi MCA, MacMahon-Pratt D. Active cutaneous leishmaniasis in Brazil induced by Leishmania donovani chagasi. Memórias do Instituto Oswaldo Cruz 81:303309, 1986a.

34. Oliveira-Neto MP, Marzochi MCA, Grimaldi Jr G, Pacheco RS, Toledo LM, Momen, H. Concurent human infection with Leishmania donovani and Leishmania braziliensis braziliensis. Annals of Tropical Medicine and Parasitology 80: 587-592, 1986b.

35. Pacheco RS, Marzochi MCA, Pires MQ. Parasite genotypically related to a monoxenous trypanosomatid of dog's flea causing opportunistic infection in an HIV positive patient. Memórias Instituto Oswaldo Cruz 93:531-537, 1998.

36. Pacheco RS, Momen H, Grimaldi Jr G, Marzochi MCA, Morel CM, Badaró R. A comparative biochemical analysis of isolates of visceral leishmaniasis from the states of Bahia and Rio de Janeiro. In: Japan Simposium on Science and Technology. Proceedings CNPq/Academia de Ciências do Estado de São Paulo, São.Paulo, volume 2, p.58-83, 1984

37. Pereira DP, Alves CR, Souza MB, Britto CC, Brazil RP, Bertho AL, Barbosa AF Identification of naturally infected Lutzomyia intermedia and Lutzomyia migonei with Leishmania (Viannia) braziliensis in Rio de Janeiro (Brazil) revealed by a non-isotopic hibridisation assay. Transaction of the Royal Society Tropical Medicine and Hygiene 99:905-913, 2005.

38. Pozio E, Grandoni L, Bettini S, Granicia M. Leishmaniasis in Tuscany (Italy): VI Canine leishmaniasis in the focus of Monte Argentario (Grosseto). Acta Troppica 38:383-93, 1981

39. Prata A. Estudo clínico e laboratorial do calazar. Tese de Livre Docência, Universidade Federal da Bahia, Salvador, 1957.
40. Prata A. Treatment of kala-azar with amphotericin B. Transactions of Royal Society of Tropical Medicine and Hygiene 57: 266-268, 1963.

41. Prefeitura da Cidade do Rio de Janeiro. Informações básicas da cidade do Rio de Janeiro. Rio de Janeiro, 1979.

42. Prefeitura da Cidade do Rio de Janeiro. Manual de controle das leishmanioses. Secretaria Municipal de Saúde, Rio de Janeiro, 2004.

43. Prefeitura da Cidade do Rio de Janeiro. Indicadores ambientais da Cidade do Rio de Janeiro. Instituto Municipal de Urbanismo Pereira Passos. Rio de Janeiro, 2005.

44. Rangel EF, Souza NA, Linger EDW, Barbosa, AF. Infecção natural de Lutzomyic intermedia (Lutz \& Neiva, 1912) em área endêmica de leishmaniose tegumentar no estado do Rio de Janeiro. Memórias do Instituto Oswaldo Cruz 79: 395-396, 1984.

45. Rangel EF, Souza NA, Wermelinger ED, Azavedo ACR, Barbosa AF, Andrade CA Flebótomos de Vargem Grande, foco de leishmaniose tegumentar no estado do Rio de Janeiro. Memórias do Instituto Oswaldo Cruz 81:347-349, 1986.

46. Sabroza PC. 0 domicílio como fator de risco leishmaniose tegumentar americana: Estudo epidemiológico em Jacarepaguá, Município do Rio de Janeiro. Tese de Mestrado, Fundação Oswaldo Cruz, Rio de Janeiro, 1981

47. Salazar MC, Pinto FC, Gouveia LR, Bacha PC, Salgueiro PF. Leishmaniose viscera (relato de um caso autóctone na cidade do Rio de Janeiro). Revista Médica 8:19, 1979 .

48. Santos SO, Arias J, Ribeiro AA, Hoffmann MP, Freitas RU, Malacco MAF Incrimination of Lutzomyia cruzi as a vector of american visceral leishmaniasis. Medical and Veterinarian Entomology 12: 315-317, 1998.

49. Secretaria de Vigilância em Saúde. Guia de vigilância epidemiológica. Ministério da Saúde, Brasília, 2005.

50. Souza MA, Sabroza PC, Marzochi MCA, Coutinho SG, Souza WJS. Flebotomíneos da área de procedência de caso humano autóctone. Memórias do Instituto Oswaldo Cruz 76:161-168, 1981

51. Souza MB, Marzochi MCA, Carvalho RW, Ribeiro PC, Pontes CS, Caetano JM, Meira AM. Ausência de Lutzomyia longipalpis em algumas áreas de ocorrência de leishmaniose visceral no município do Rio de Janeiro. Cadernos de Saúde Pública 19: 109-118, 2003

52. Souza MB, Wermelinger ED, Machado RNM, Ponte CS, Meródio JC, Marzoch MCA, Brandoline MB, Castelo FCB, Andrade MV. Monitoramento de vetores de leishmanioses no município do Rio de Janeiro, RJ. Revista de Patologia Tropical 34: 786,2005

53. Teixeira R. Experiências vividas com a leishmaniose visceral, 1954-1980; aspectos epidemiológicos, sorológicos e evolutivos. Tese. Universidade Federal da Bahia, Salvador, 1980

54. Toledo LM. Leishmaniose tegumentar e visceral em área peri-urbana no município do Rio de Janeiro. Tese de Mestrado, Fundação Oswaldo Cruz, Rio de Janeiro, RJ, 1987.

55. Toledo LM. Marzochi MCA, Sabroza PC, Marzochi KBF, Momen H Grimaldi-Filho G. Caracterização epidemiológica de um foco de transmissão simultânea de leishmaniose tegumentar e leishmaniose visceral em área periurbana no Município do Rio de Janeiro. Revista da Sociedade Brasileira de Medicina Tropical 21 (supl): 87-88, 1988.

56. Vieira JBF, Coelho GE. Leismaniose visceral ou calazar: aspectos epidemiológicos e de controle. Revista da Sociedade Brasileira de Medicina Tropical 31 (supl II): 85-92, 1998 